\title{
Employer's Refusal To Bargain and the NLRB's Remedial Powers: The H.K. Porter Case
}

The recent $H . K$. Porter case ${ }^{1}$ brings into sharp focus problems that have long troubled the National Labor Relations Board in enforcing the duty to bargain in good faith ${ }^{2}$ and in fashioning remedies to redress violations of this duty. ${ }^{3}$ The primary goal of the National Labor Relations Act is the promotion of industrial peace, ${ }^{4}$ but this is not its only goal. It preserves the freedom of contract of employers and unions; ${ }^{5}$ section 8 (d) of the Act provides that the duty to bargain collectively "does not compel either party to agree to a proposal or require the making of a concession." "The Act creates a framework for collective bargaining, but it relies upon the economic power of the negotiating parties to resolve bargaining impasses. ${ }^{7}$ Reconciling these often conflicting policies of industrial peace and freedom of contract is the major difficulty confronting the Board in regulating the process of collective bargaining. ${ }^{8}$ In this

1 H.K. Porter Co., 153 N.L.R.B. 1370 (1965), enforced sub nom. United Steelworkers v. NLRB, 363 F.2d 272 (D.C. Cir.), cert. denied, 385 U.S. 851 (1966), order clarified, 389 F.2d 295 (D.C. Cir. 1967), remanded, 172 N.L.R.B. no. 72 (1968).

2 National Labor Relations Act [hereinafter NLRA] $\S 8(d), 8(a)(5)$ (employer), 8(b)(3) (union); 29 U.S.C. $\$ \S 158(d)$, (a)(5), (b)(3) (1964). There are not many cases charging unions with refusal to bargain. This is easily explained: "Because labor organizations are formed primarily when employees desire to negotiate with their employer, the cases in which unions are charged with unlawful refusal to bargain rarely involve any allegation of an outright refusal by the union to meet or negotiate with the employer. Ordinarily, cases in which a union is alleged to have refused to bargain involve the legality of some proposal insisted on by the union or upon a technical point of bargaining . . . "16 NLRB ANN. REP. 220-21 (1951). See Comment, Union Refusal to Bargain: Section $8(b)(3)$ of the National Labor Relations Act, 71 HARv. L. REv. 502 (1958).

3 NLRA § 10(c), 29 U.S.G. § 160(c) (1964). See generally McCullough, New NLRB Remedies, 30 U.S.L.W. 2133 (1961); McCullough, An Evaluation of the Remedies Available to the NLRB, 15 LAB. L.J. 755 (1964); McCullough, The Consequences of NLRB Action on Good Faith Bargaining, 17TH ANNUAL N.Y.U. CONFERENCE ON LABOR 415 (1964); Comment, Employer Pre-Election Coercion: A Suggested Approach for Effective Remedial Action, 115 U. PA. L. REv. 1112 (1967); Comment, NLRB Remedies for the Runaway Shop: Loopholes in the National Labor Policy, 1967 IrL. L.F. 649; Comment, The Need for Creative Orders Under Section 10(c) of the National Labor Relations Act, 112 U. PA. L. REv. 69 (1963).

4 See Findings and Policies, NLRA § 1, 29 U.S.C. § 151 (1964).

5 See Wellington, Freedom of Contract and the Collective Bargaining Agreement, 112 U. PA. L. REv. 467 (1964).

6 NLRA § 8(d), 29 U.S.C. § 158(d) (1964).

7 NLRB v. Insurance Agents' Int'l Union, 361 U.S. 477 (1960).

8 At the time of the passage of the Act, it was believed that these two policies need not conflict. See NLRB v. Jones \& Laughlin Steel Corp., 301 U.S. 1, 45 (1937): "The theory 
context, the H.K. Porter case raises a significant question: To what extent may the Board, in remedying a refusal to bargain, compel inclusion of particular substantive provisions in a collective bargaining agreement?

After lengthy litigation, the District of Columbia Circuit Court of Appeals answered this question by holding that "where an employer has twice been found to have violated his duty to bargain in good faith" the Board may impose substantive contract terms as a remedy. ${ }^{9}$ Specifically, the court held that the H.K. Porter Company, which had been found to have violated its $8(a)(5)$ duty by refusing to accede to a union demand for a checkoff, could be ordered to grant the checkoff in exchange for a reasonable concession by the union. Although the circumstances of the H.K. Porter case provided an appealing basis for stretching the Board's remedial power, the court's decision involves serious tensions with the underlying presuppositions of the Act.

\section{The Case}

In October 1961, the Steelworkers won an election at the Disston Division-Danville Works of the H.K. Porter Company, Danville, Virginia, and was certified as the bargaining agent for about 300 employees. By November 1962, twenty-eight bargaining sessions had been held, but no agreement had been reached. In April 1963, the union charged the employer with bad faith bargaining, and a complaint was issued. The trial examiner issued his decision in September. He found that the company's insistence on a no-strike clause while refusing to agree to arbitration and its unilateral changes in certain working conditions demonstrated bad faith. ${ }^{10} \mathrm{He}$ recommended a cease and desist order. The company filed no exceptions, and in April 1964 the Board adopted the examiner's recommended order. Three months later the Fourth Circuit entered a decree summarily enforcing the Board's order. ${ }^{11}$

In October 1963, the two parties had resumed bargaining. At the time fourteen issues remained open. During twenty-one meetings in the year that followed, ten items were withdrawn by the union and one by the employer, leaving three issues unresolved-a dues checkoff, wages, and

of the Act is that free opportunity for negotiation with accredited representatives of the employees is likely to promote industrial peace and may bring about the adjustments and agreements which the Act in itself does not attempt to compel."

9 United Steelworkers v. NLRB, 389 F.2d 295, 302 (D.C. Cir. 1967).

10 The finding of a refusal to bargain based on insistence on a no-strike clause while rejecting arbitration has been criticized in depth. See Meltzer, The Supreme Court, Arbitrability and Collective Bargaining, 28 U. Crr. L. REv. 464, $478-79$ (1961).

11 Both the Board and court opinions involving the first refusal to bargain charge are unreported. 
insurance. The dues checkoff proved to be the thorniest of these. The chief negotiator for the company rejected every union proposal regarding the checkoff, ${ }^{12}$ not on grounds of inconvenience-the company already deducted for U.S. Savings Bonds, dependents' coverage under a health insurance plan, United Givers Fund, and a Good Neighbor Fund -but on the ground that the collection of union dues was union business which H.K. Porter need not foster. In September 1964, the union again charged the company with an $8(a)(5)$ violation. The Board in July 1965 affirmed the trial examiner's finding of a violation..$^{13}$ The crucial issue before the Board was whether the company's position on the dues checkoff "was a device to frustrate agreement on a contract ... or ... merely ... "hard bargaining." "14 In deciding it was the former, the trial examiner gave particular weight to two findings. First, the employer's assertion that the union should strike to get the dues checkoff not only ran counter to the objectives of the Act, but also in light of existing payroll deductions, demonstrated an intention to forestall agreement by the expedient of disparaging the union in the eyes of its members. Second, the reason given for not granting the checkoff was inconsistent with the obligations of the employer under the Act. The Board issued a cease and desist order and ordered the employer to bargain with the union.

In enforcing the Board's order nearly a year later, Judge J. Skelly Wright, speaking for a two-to-one majority of the District of Columbia Circuit Court, agreed that there had been an 8(a)(5) violation and addressed himself principally to the union's contention that the Board's remedy should have required the company to withdraw its objections to the checkoff. The court hinted broadly that any further refusal to bargain by the employer should lead to contempt proceedings but made clear "that under Section 8(d) [the employer] cannot be compelled to agree to a proposal or make a concession." 15 As to the checkoff, the court indicated, somewhat ambiguously, that the parties were to negotiate over it, and that the employer could not fabricate any new reasons for denying it. ${ }^{16}$ Judge Wilbur K. Miller dissented, asserting that he had "seldom seen a record so barren of support for the decision of the examiner and the Board. ..."17 The company applied for a writ of certiorari.

12 Included among the union proposals were access to the plant by the union's financial secretary during lunch hours and collection of dues by union stewards during nonworking hours. H.K. Porter Co., 153 N.L.R.B. 1370, 1372 (1965).

13 H.K. Porter Co., 153 N.L.R.B. 1370 (1965).

14 Id. at 1372.

15 United Steelworkers v. NLRB, 363 F.2d 272, 276 (D.C. Cir. 1966).

$10 \mathrm{Id}$. at 276 n.16.

17 Id. at 281. 
While the application was pending, the company and the union continued negotiations, leaving the checkoff question open. The company drew up a contract, signed it, and forwarded it to the union, postponing the checkoff issue for further bargaining if and when the NLRB order became final. After the Court denied certiorari, ${ }^{18}$ the union demanded a checkoff, and, in a subsequent meeting, urged that the company was obligated to grant a checkoff and only the wording remained open. The company disagreed, contending that it was not obligated to grant the checkoff, but only to bargain in good faith in an attempt to establish a system of dues collection. Subsequently the union signed the agreement and, instead of continuing negotiations on the checkoff, filed a motion with the District of Columbia Circuit in February 1967 requesting the court to clarify its enforcement order.

In late March, the court denied the union's request, stating "that under the circumstances a contempt proceeding ... would be more appropriate to test the company's compliance with the decree."19 The union moved for contempt proceedings in early April. In late June, the Board rejected the union's motion for contempt, apparently accepting the company's interpretation of the court's enforcement order. In July, the union filed a motion with the court of appeals for reconsideration of its earlier motion for clarification of the enforcement order. The court granted the motion.

In a decision handed down in December 1967, the court again split two-to-one, with Judge Wright writing the opinion and Judge Miller dissenting without opinion. The court held that it was within the Board's remedial powers to order a "checkoff in return for a reasonable concession by the union." 20 The court remanded the case to the NLRB, making it clear that the union's and not the company's interpretation of its previous enforcement order was to be given effect.

The court, while recognizing that remedies which impinge on freedom of contract "are not to be casually undertaken," declared that "an equally important policy of the Act is to equalize the bargaining power of employees and employers." The major purpose of the $8(a)(5)$ duty is "to make meaningful" the fundamental right of workers to bargain collectively provided by section $7 . .^{21}$ Ordering the employer to grant a checkoff "obviously intrudes on freedom of contract," 22 but it is "at most a minor intrusion." A checkoff provision, "likely to be of life or death

18385 U.S. 851 (1966).

19 Letter from clerk of D.C. Circuit Court of Appeals to all parties, Mar. 22, 1967.

20 United Steelworkers v. NLRB, 389 F.2d 295, 302 (1967).

21 Id. at 300.

$22 I d$. at 301. 
import to the fledgling union," is of "no consequence whatever to the employer."23

A Board-ordered concession on this provision by the employer, the court reasoned, may be "the only way to guarantee the workers' rights to bargain collectively"24 and for the employer "to purge the stain of bad faith that has already soiled its position." The court found no bar to its order in section 8(d). This provision, the court held, relates to the determination of whether an $8(a)(5)$ violation occurred, not to the scope of the remedy that may be necessary to cure the violation. ${ }^{25}$

\section{The Refusal To Bargain}

Dues checkoff is a mandatory subject of bargaining. ${ }^{26}$ Either party may bargain to an impasse over it, ${ }^{27}$ and section 8 (d) sanctions an employer's refusal to make a concession on it. ${ }^{28}$ The statutory right to refuse to accede to the union's demand for a dues checkoff, however, cannot be used "as a cloak ... to conceal a purposeful strategy to make bargaining futile or fail." 29 In determining whether an employer's refusal to grant a checkoff is such a "cloak," the Board has begun to scrutinize the reasons given by the employer for rejecting the demand. The Board has taken the position that, since the checkoff imposes little burden on the employer but is of great benefit to the union, there are only two legitimate reasons which justify an employer's refusal to grant it: ${ }^{30}$ (1) it is too expensive and imposes too much of a burden on the employer's clerical staff; ${ }^{31}$ (2) it is being reserved for trading purposes, as a concession to be offered at the bargaining table in exchange for a union concession. ${ }^{32}$ Absent one of these reasons, the Board is likely to find an 8(a) (5) violation on the ground that the employer's refusal to grant a checkoff is being used to forestall agreement. ${ }^{33}$

\footnotetext{
23 Id. at 302.

$24 \mathrm{Id}$. at 301.

$25 \mathrm{Id}$. at 299.

26 NLRB v. Reed \& Prince Mfg. Co., 205 F.2d 131 (Ist Cir.), cert. denied, 346 U.S. 887 (1953); NLRB v. Andrew Jergens Co., 175 F.2d 130 (9th Cir. 1949).

27 NLRB v. Wooster Div. of Borg-Warner Corp., 356 U.S. 342 (1958).

28 NLRA \& 8(d), 29 U.S.C. \& 158(d) (1964).

29 NLRB v. Herman Sausage Co., 275 F.2d 229, 232 (5th Cir. 1960).

30 Brief for NLRB at 14, United Steelworkers v. NLRB, 363 F.2d 272 (D.C. Cir. 1966). See Roanoke Iron \& Bridge Works, Inc., 160 N.L.R.B. 175 (1966), enforced sub nom. United Steelworkers v. NLRB, 390 F.2d 846 (D.C. Cir. 1967), cert. denied, 391 U.S. 904 (1968).

31 H.K. Porter Co., 153 N.L.R.B. 1370, 1373 (1965); Farmer's Co-operative Gin Ass'n, 161 N.L.R.B. 887 (1966). This argument is quickly negated by the Board if the employer makes payroll deductions for government bonds or charities.

32 Cf. Stevenson Brick \& Block Co., 160 N.L.R.B. 198 (1966); Alba-Waldensian, Inc., 167 N.L.R.B. no. 101 (1967).

38 Roanoke Iron \& Bridge Works, Inc., 160 N.L.R.B. 175, enforced sub nom. United
} 
In assessing the employer's justifications for refusing the checkoff, the Board is departing from precedent. ${ }^{34}$ It has long been settled that the Board "may not ... . sit in judgment upon the substantive terms of collective bargaining agreements." 35 The National Labor Relations Act does not establish generally applicable standards for working conditions, ${ }^{36}$ nor does it authorize the Board to prescribe what collective bargaining agreements must contain. ${ }^{37}$ Indeed, the adoption of section 8(d) was "an attempt by Congress to prevent the Board from controlling the settling of the terms of collective bargaining agreements." 38

The Board's appraisal of the employer's good faith on the basis of the justifications he offers for refusing to accept a checkoff not only involves passing judgment on the reasonableness of his position, but also applies pressure on him to make a concession. ${ }^{39}$ The Board refuses to recognize

Steelworkers v. NLRB, 390 F.2d 846 (D.C. Cir. 1967), indicates the extent to which the Board is willing to go to find an 8(a)(5) violation for refusal to grant a checkoff. In 1951, the Steelworkers won an election and bargained with the company. The company adamantly rejected the union's checkoff proposal, but the two sides reached agreement on a contract. By the time it expired, the union had lost its majority status. In 1961, another union, the Steel Fabricators Union of Roanoke, Virginia, bargained with the company. Initially the company resisted the checkoff, but eventually gave in on the issue. This union, too, expired with the contract it had negotiated. In 1964, the Steelworkers resumed bargaining with the company. The company vigorously resisted the union, but the Steelworkers won a representation election. The company rejected the Steelworkers' checkoff demand "on the principle that collection of union dues was union business." 160 N.L.R.B. at 181. It maintained that stance through six months of bargaining and six months of a strike. On this record-the company's vigorous campaign against the union and its refusal to grant a checkoff-the Board held the company to have violated $\$ 8(a)(5)$. The District of Columbia Circuit, in a 2-1 decision, enforced the Board's cease and desist order. The case is noted in 81 Harv. L. REv. 1874 (1968).

34 Judge Magruder's statement in NLRB v. Reed \& Prince Mfg. Co., 205 F.2d 131, 134-35 (1st Gir. 1953) has been considered definitive in setting guidelines for the Board's assessment of bargaining positions to determine whether an 8(a)(5) violation is present: "[W] hile the Board cannot force an employer to make a 'concession' on any specific issue or to adopt any particular position, the employer is obliged to make some reasonable effort in some direction to compose differences with the union, if $\S 8(a)(5)$ is to be read as imposing any substantial obligation at all." (Emphasis in original.) Under this formulation, it is necessary to look at the bargaining as a whole to see whether there has been some movement in the direction of settlement. The Board, as Judge Magruder points out, is not permitted to "adopt any particular position." By allowing the employer to justify a refusal to grant a checkoff only on grounds of expense or use as a bargaining counter, the Board is clearly moving away from Judge Magruder's formulation.

35 NLRB v. American Nat'l Insur. Co., 343 U.S. 395, 404 (1952). The dissenting opinion also supported this position. Id. at 412. See McCullough Corp., 132 N.L.R.B. 201, 215-16 (1961).

36 Terminal R.R. Ass'n v. Brotherhood of R.R. Trainmen, 318 U.S. 1, 6 (1943).

37 NLRB v. Whittier Mills Co., 123 F.2d 725, 728 (5th Cir. 1941).

38 NLRB v. Insurance Agents' Int'l Union, 361 U.S. 477, 487 (1960), quoting NLRB v. American Nat'l Insur. Co., 343 U.S. 395, 404 (1952).

39 Cox, The Duty To Bargain in Good Faith, 71 HARv. L, Rev. 1401, 1419 (1958). It is interesting to note that in NLRB v. Truitt Mfg. Co., 351 U.S. 149 (1956), in which the Court required the employer to give the union evidence of his asserted inability to 
that the employer may have philosophical reasons or no reason at all for refusing to accede to the checkoff demand, and yet not be using that position to frustrate the bargaining process. The employer may be opposed to helping the union maintain the allegiance of a majority of the workers, but nonetheless willing to enter into an agreement with the union as long as it has a majority. Like the H.K. Porter Company, some employers may regard the collection of dues as "union business." Others may have more sophisticated reasons for not wanting to grant a checkoff..$^{40}$ The important point, made by the same Fifth Gircuit panel which held that a bargaining position may not be used "as a cloak ... to conceal a purposeful strategy" to frustrate bargaining, is that

... the making of the labor agreement is not for either Board or Court. ... [The] employer may have either good or bad reasons, or no reasons at all, for insistence on the inclusion or exclusion of a proposed contract term. ... The Government, through the Board, may not subject the parties to direction by ... the means of determining that the position is inherently unreasonable, or unfair, or impracticable, or unsound. ${ }^{41}$

The court of appeals in $H . K$. Porter attempted to meet this objection by pointing to the insignificance of the checkoff to the employer and its "life or death" importance to the union. ${ }^{42}$ But any form of union security, viewed in terms of dollars and cents, is trivial to the employer.43 This is true of a union shop provision as well. Neither a checkoff nor a union shop costs the employer directly in money terms. What must be recognized, however, is that the two parties are locked into a relationship by the Act. The employer must recognize the union and bargain with it, but the exact terms of this bargaining relationship-whether

pay a wage increase, the Court did not say that the evidence had to prove his inability to pay. In other words, the Court refused to scrutinize the reasonableness of the employer's assertion of inability to pay once he had shown the union data on his financial situation.

40 For instance, the employer could argue that he does not want to prefer the union to his employees" other creditors and resist the checkoff, or that if he "horse trades" and gives in on the checkoff, it will cost his employees in terms of wages, and he does not want to drive a wedge between himself and his workers by depriving them of better pay or working conditions. Finally, he could argue, although this is not applicable in H.K. Porter because of the union's proposals (see note 12 supra), that the union, and not the employer, should be responsible for collecting union dues because it will afford the men an opportunity to communicate with their representatives, and give them a chance to gripe. Such an opportunity, the employer could argue, would improve morale in the plant because the men will know their grievances are being heard. But cf. AlbaWaldensian, Inc., 167 N.L.R.B. no. 101 (1967).

41 NLRB v. Herman Sausage Co., 275 F.2d 229, 281 (5th Cir. 1960).

42 United Steelworkers v. NLRB, 389 F.2d 295, 302 (D.C. Cir. 1967).

43 See Cox, supra note 39, 71 HARv. L. REv. at 1419-22. 
one party will dominate, for example-are determined by the parties themselves and principally by the economic force that the parties can muster. ${ }^{44}$ A checkoff or union shop strengthens the union and increases its ability to press home its demands in later negotiations. Viewed in this light, it is not as trivial to the employer as the court asserts. ${ }^{45}$ Surely, it is not a requirement of the Act that the employer do everything in his power to bolster the union. In fact, section 8(c) and the employer speech cases $^{46}$ indicate that the employer is entitled to resist unionization as long as he neither promises benefits nor threatens reprisal. ${ }^{47}$ Moreover, the statement by the court that the checkoff is included in 92 per cent of all manufacturing contracts ${ }^{48}$ does not ipso facto make the checkoff issue insignificant. Ninety-six per cent of all contracts provide for arbitration $^{49}$ and 90 per cent for seniority, ${ }^{50}$ hardly trivial contract terms.

Implicitly in its clarification order and explicitly in its enforcement order, ${ }^{51}$ the court took a dim view of the employer's uncompromising stand on the checkoff issue. This intransigence, linked with the insignificance of the issue, clearly established the employer's bad faith in the court's view. As the Board has recognized, however, "There comes a point in any negotiation where the positions of the parties are set and beyond which they will not go." ${ }_{22}$ The real test is not intransigence on one issue, but the party's overall desire to reach agreement. ${ }^{53}$ In $H . K$. Porter the employer was willing to enter into an agreement-indeed, it signed one, forwarded it to the union, and the union signed-but resisted the checkoff demand. Unless refusal to grant a checkoff is a per se violation-which it has not been ${ }^{54}$ - the employer's intransigence by

44 NLRB v. Insurance Agents' Int'l Union, 361 U.S. 477 (1960); cf. American Ship Building Co. v. NLRB, 380 U.S. 300 (1965).

45 The Taylor Commission, which studied public employee unionism in New York, argued that the threat of deprivation of checkoff rights to a striking union would deter strikes. See N.Y. Governor's Comm. on Publig Employee Relations, Final Report 64-65 (1966).

48 See, e.g., NLRB v. Yorkell, 387 F.2d 751 (2d Cir. 1967).

47 It seems from the election cases that an employer may make anti-union speeches during working hours while not allowing the union to reply. See, e.g., NLRB v. Avondale Mills, 357 U.S. 357 (1958). This would indicate that an employer's doing something that he does not allow the union to do is not necessarily disparagement. See notes 58-66 infra, and accompanying text.

48389 F.2d at 302 . Of all contracts, only $83 \%$ have provisions for a dues checkoff. 2 BNA Collective Bargaining Negotiations and Contracts 87:3 (1967).

$49 \mathrm{Id}$. at $5 \mathrm{l}: 6$.

$50 \mathrm{Id}$. at $75: 1$.

$51363 \mathrm{~F} .2 \mathrm{~d}$ at 276.

52 Philip Carey Mfg. Co., 140 N.L.R.B. 1103, 1105 (1963).

53 Comment, "Boulwareism": Legality and Effect, 76 HARv. L. Rev. 807, 811 n.38 (1963).

54 The Board has relied on totality of circumstances in finding a refusal to bargain, although at times the intransigence on the checkoff issue seems to be the dominant factor 
itself does not violate the statute. ${ }^{55}$ Moreover, is only the employer's adamancy to be prohibited? In $H . K$. Porter the union made it very clear that a contract without some form of checkoff would be unacceptable. ${ }^{56}$ In at least one case it has been held that mutual rigidity on an issue does not mean that the employer has refused to bargain. ${ }^{57}$

The Board found that the company's purpose in adopting the position that the union should strike to achieve a checkoff rather than file an unfair labor practice charge was to disparage the union in the eyes of the employees in order to forestall agreement. ${ }^{58}$ Similarly, the court of appeals reasoned that the employer's refusal to grant a checkoff and thus put the union in stronger bargaining position was, in effect, a denial of the employees' section 7 rights. ${ }^{59}$

Both these arguments run counter to the Supreme Court's opinion in Insurance Agents. ${ }^{60}$ Disparagement traditionally refers to rejection of either the process of collective bargaining ${ }^{61}$ or the union's role in it. ${ }^{62}$ The H.K. Porter Company rejected neither. It was apparently willing to sign an agreement with the union but balked at the terms the union demanded. It might be argued that refusal to accede to a demand which is an indicium of the union's status as bargaining agent is equivalent to rejection of the union's role in the bargaining process. But this argument would carry the disparagement test to the point where an employer violates the Act every time it refuses to accept a proposal the union considers important. ${ }^{63}$

Moreover, if the union were successful in a strike for a checkoff, it is difficult to see how it would be "disparaged" in the eyes of the employees. The Board seems to have assumed that the strike would fail. If this is so, however, it indicates that the union lacked sufficient economic strength to win its demands. "Disparagement" results, not be-

in finding a violation. See Alba-Waldensian, Inc., 167 N.L.R.B. no. 101 (1967); Roanoke Iron \& Bridge Works, Inc., 160 N.L.R.B. 175 (1966); H.K. Porter Co., 153 N.L.R.B. 1370 (1965). Moreover, since the reasonableness of the employer's refusal is scrutinized, this is unlike a per se violation where reasonableness is not at issue.

55 See NLRB v. Wooster Div. of Borg-Warner Corp., 356 U.S. 342 (1958); Comment, supra note 53, 76 HARv. L. REv. 807.

so 363 F.2d at 276.81 (Miller, J. dissenting).

57 NLRB v. Standard Trouser Co., 162 F.2d 1012 (4th Cir. 1947); cf. NLRB v. Whittier Mills Co., 123 F.2d 725 (5th Cir. 1941); Proctor \& Gamble Mfg. Co., I60 N.L.R.B. 334 (1966).

58153 N.L.R.B. at 1373.

50389 F.2d at $300-01$.

60 NLRB v. Insurance Agents' Int'l Union, 361 U.S. 477 (1960).

01 NLRB v. Montgomery Ward \& Co., 133 F.2d 676 (9th Cir. 1943). See Cox, supra note 39, 71 Harv. L. REv. at 1415.

62 General Electric Co., 150 N.L.R.B. 192 (1964).

63 See Cox, supra note 39, 71 Harv. L. Rev. at 1415. 
cause the union is forced to rely upon economic weapons, but because it is not firmly enough established to use them effectively.

The court and the Board are mistaken in indicating that the Act intended to strengthen the union's position in these circumstances. ${ }^{64}$ One purpose behind the Act was the equalization of bargaining power of employer and employees, as the court asserts. ${ }^{65}$ To achieve this purpose, the Act guaranteed the employees' right to organize and select a bargaining representative and imposed a corollary duty on the employer to recognize and bargain with their representative. But this is not equivalent to assuring the union's ability to secure all that the employees demand from the employer. Board intervention to achieve this latter purpose would seem to be an attempt to "equaliz[e] disparities of bargaining power between employer and union"-precisely the type of Board action the Supreme Court condemned in Insurance Agents. ${ }^{\circ 6}$

A central problem in the Board's overall approach to the dues checkoff issue, which also has important implications regarding the remedy imposed in H.K. Porter, is that, in approving the use of the checkoff as a trading device, the Board is moving closer to regulating the substantive terms of the agreement. How much is a checkoff worth? May an employer withhold a wage increase in trade for a checkoff? Once the Board begins policing the reasonableness of the rhetoric, it is not far from policing the reasonableness of the positions. ${ }^{67}$ Given the language and legislative history of section $8(\mathrm{~d})$, this is not what Congress had in mind.

The reasoning in H.K. Porter ignores the realities of bargaining. It is unrealistic to expect an employer to take a position at the bargaining table that is anything less than firm. He must appear resolute, willing to incur a strike over an issue in order for the union to assess its economic position and perhaps tone down its demands. If the employer must announce that he will trade on a dues checkoff, it will undermine his bargaining position. This is especially unrealistic where a party intends to reserve a particular concession for future bargaining, when his position may not be as strong as it is currently. Collective bargaining is, after all, a recurring process, and each contract negotiation is influenced by those which preceded it and those likely to follow. ${ }^{68}$

64 There seems to be a basic inconsistency in the court's reasoning. At one point, it argues that the checkoff is rather trivial (389 F.2d at 302); at another, it indicates that the granting of a checkoff would put the union in a stronger bargaining position (Id. at 301).

$65 \mathrm{Id}$. at 300 .

66361 U.S. at 490. But cf. NLRB v. Truck Drivers Union, 353 U.S. 87 (1957). See generally Meltzer, The Lockout Cases, 1965 Sup. Cr. Rev. 87.

67 See NLRB v. American Nat'l Insur. Co., 343 U.S. 395 (1952).

68 United Steelworkers v. NLRB (Roanoke Iron \& Bridge Works, Inc.), 390 F.2d 846, 856 (D.C. Cir. 1967) (Burger, J. dissenting). 


\section{THE REMEDY}

Although the Board has broad and flexible remedial powers under section $10(c)$, its orders must be remedial rather than punitive ${ }^{69}$ Courts have interpreted this limitation to require that the orders perform a restorative, rather than deterrent or penal, function. ${ }^{70}$ The imposition of a dues checkoff as a remedy in a refusal to bargain case, instead of restoring the parties to their original positions, in fact gives the union something which, but for the $8(a)(5)$ violation, it probably could not have achieved.

In addition, section 10 (c) limits the Board to remedies which will "effectuate the policies of the Act." 71 This requires a delicate balancing of the policies of industrial peace and freedom of contract. The court of appeals appears to have recognized the importance of the latter policy. ${ }^{72}$ But in viewing the opposing policy as equalization of bargaining power, rather than the promotion of industrial peace, the court gives insufficient weight to the impact of the Board's order on the relationship between the parties. The Board acting as umpire, deciding the reasonableness of positions, may not promote industrial peace. If either party finds a Board decision unpalatable, it may well become increasingly intransigent on other issues rather than more willing to find a common ground. The experience with compulsory contract arbitration is that arbitrators search not for an agreement that contains "eternal truth," but for one that is acceptable to both parties. Given this uncertainty as to the effectiveness of the Board's intervention as a means of promoting industrial peace, as well as an intrusion of major proportions into the policy of freedom of contract, ${ }^{73}$ the remedial approach proposed by the court of appeals appears to upset the delicate policy balance of the Act.

Furthermore, the decision in H.K. Porter limits the scope of section 8(d). The court held that the Board could impose "a checkoff in return for a reasonable concession by the union" 74 as a remedy for a refusal to bargain. In policing what is a "reasonable concession" by the union, the Board must place a value on a dues checkoff. The Board would be imposing its will on the substantive terms of the agreement, contrary to the holding of the Supreme Court. ${ }^{75}$

60 Consolidated Edison Co. v. NLRB, 305 U.S. 197, 235-36 (1938). See Republic Steel Corp. v. NLRB, 311 U.S. 7, 11 (1940).

70 See Comment, supra note 3, 115 U. PA. L. REv. at 1112-13 n.5. For an excellent definition of "remedial," see NLRB v. Coats \& Clark, Inc., 241 F.2d 556, 561 (5th Cir. 1957).

71 NLRA § 10(c), 29 U.S.C. $\$ 160(c)$ (1964).

72389 F.2d at 300.

73 See Wellington, supra note 5, 112 U. PA. L. REv. at 467-80.

74389 F.2d at 302.

75 See NLRB v. Insurance Agents' Int'l Union, 361 U.S. 477 (1960). 
The court argues, however, that section 8 (d) is not relevant to the scope of the remedy that may be necessary to cure an $8(a)(5)$ violation. It holds that a company which "has repeatedly flouted its Section 8(a)(5) duty" may be required to make reasonable counteroffers or even a concession in order "to purge the stain of bad faith that has already soiled its position." 76 Even assuming that this would "effectuate the policies of the Act"-an assumption that requires giving more weight to equalization of bargaining power as a policy than seems to be justifiable ${ }^{77}$ this test measures the validity of the Board's remedy by the degree of bad faith shown by a party. Is "repeatedly flout[ing]" the $8(a)(5)$ duty something other than violating it more than once? When is an employer "stained" by bad faith; when did he merely fail to bargain in good faith? There is obviously no easy answer. It may be suggested, however, that in H.K. Porter the court was too readily swayed by the prior history of the case. It characterized H.K. Porter as a "recalcitrant employer determined to defeat the effective unionization of his plant by illegally opposing organizational and bargaining efforts every step of the way." "78

Moreover, section 10 (c) orders are supposed to be in concert with the policies of the Act, not contrary to them. Suppose an employer closes his plant in New York and moves to Florida to avoid having to deal with a newly elected union. Can the Board, in redressing the problem of the "runaway shop," require that the employer recognize the New York union as the representative of his employees, even if the Florida employees do not want a union? This remedy would deal effectively with the "runaway shop," but it would also deprive the Florida employees of their section 7 rights to choose their own representatives. The District of Columbia Circuit Court held in Garwin Corp. v. $N L R B^{79}$ that such a remedy impinges on the Florida employees' section 7 rights and held it outside the scope of the Board's remedial powers. ${ }^{80}$

The primary force behind the court's proposal of the imposition of substantive terms as a remedy in refusal to bargain cases was probably the current dissatisfaction with the Board's remedial powers. ${ }^{81}$ Presently,

76389 F.2d at 299.

77 See text accompanying notes 64-66 supra.

78389 F.2d at 301 and n.10.

79374 F.2d 295 (D.C. Cir.), cert. denied, 387 U.S. 942 (1967). The case was remanded to the Board which reached its new decision, reported in 67 L.R.R.M. 1296 (1967).

80 The trial examiner in Roanoke found the idea of imposition of substantive terms as a remedy for refusal to bargain "inadvisable, if not in excess of the Board's authority . . ." 160 N.L.R.B. at 182. The Board adopted the trial examiner's opinion as its own. See Ross, Analysis of Administrative Process Under Taft-Hartley, 1966 BNA LABOR RELATIONS YEARBOOK 299, 319.

81 See Ross, supra note 80; Bok, The Regulation of Campaign Tactics in Representation Elections Under the NLRA, 78 FARv. L. REv. 38 (1965); sources cited in note 3 supra. 
if a party continues to refuse to bargain after an enforcement order, only the Board can institute contempt proceedings. ${ }^{82}$ In the H.K. Porter and Roanoke enforcement orders, as well as in the original denial of clarification in H.K. Porter, two panels of the District of Columbia Circuit Court encouraged the Board to move for contempt against the employer if it did not follow the Board's orders.

Contempt is a time-consuming procedure. ${ }^{83}$ It is rarely used because enforcement orders are effective enough that the Board need not turn to $\mathrm{it}^{84}$ and because proving contempt is so difficult that the Board is reluctant to invoke it. In an action to enforce a cease and desist order, the court often defers to the Board's expertise and seeks only substantial evidentiary support for the Board's order in the record taken as a whole. ${ }^{85}$ In a contempt proceeding the court must independently find willful disobedience of the order, ${ }^{86}$ with the Board bearing the burden of proving violation of the enforcement order by a "preponderance of the evidence," 87 "clear and convincing proof," 88 or "more than a preponderance of the evidence." 89

The imposition of substantive contract terms is, to say the least, an extraordinary remedy. It should be used, if at all, only under the most drastic of circumstances-where an employer's refusal to bargain is clear and convincing. If this limitation on the remedy is imposed, then the Board will be confronted with the same difficulty of proof as in contempt cases. And given the same standard of proof, the Board should choose contempt, a remedy that is consistent with the Act and sanctioned by both Congress and the courts, rather than a remedy that impinges on the policy enunciated in section 8(d) of the Act.

It has been suggested that greater specificity in Board orders would make proof of contempt easier. ${ }^{90}$ While such specificity would make

82 NLRA $\$ 10,29$ U.S.C. $\$ 160$ (1964).

83 The Ross study tends to add weight to this proposition. Ross, supra note 80 , at 302-09; N.Y. Times, Oct. 16, 1966, at 1.

84 The Board has used contempt about six times per year on the average. See 16-81 NLRB ANN. REP. (1951-66).

85 NLRA \& 10(e), 29 U.S.C. § 160(e) (1964); Universal Camera Corp. v. NLRB, 340 U.S. 474 (1950).

86 Comment, supra note 3, 112 U. PA. L. REv. at 85. While most actions for contempt are for civil contempt, it is interesting to note that conviction for criminal contempt may become easier because it is arguable that jury trials are no longer required. United States v. Barnett, 376 U.S. 681 (1964). See Teff,, United States v. Barnett: "Twas a Famous Victory," 1964 SUP. CT. REv. 123.

87 NLRB v. Reed \& Prince Mfg. Co., 196 F.2d 755, 760 (1st Cir. 1952).

88 NLRB v. Local 5881, UMW, 323 F.2d 853 (6th Cir. 1963); NLRB v. Spartanburg Sportswear Co., 278 F.2d 312 (4th Cir. 1960); NLRB v. Standard Trouser Co., 162 F.2d 1012, 1014 (4th Cir. 1947).

89 Kansas City Power \& Light Co. v. NLRB, 137 F.2d 77, 79 (8th Cir. 1943).

00 Comment, supra note 3, 112 U. PA. L. REv. at 85-86. 
compliance with the order easier for both parties, it is doubtful that the Board will turn in this direction. If the Board were required to pinpoint the violation precisely, such cases as H.K. Porter would never be unfair labor practices. Leaving aside the dubious "disparagement" finding, ${ }^{91}$ the sum and substance of the violation in H.K. Porter is that the employer refused to grant the union a checkoff. Unless such a refusal is now a per se $8(a)(5)$ violation, the Board's case against the H.K. Porter Company was weak, at best.92

\section{ConcLusion}

On remand from the D.C. Circuit, the Board in July 1968 held:

As Respondent has repeatedly violated Section 8(a)(5) and admittedly had no business reason for opposing the checkoff, and as its only reason for such opposition was to frustrate agreement with the Union, we conclude, in accordance with the Court's rationale, that an order to grant checkoff is warranted in the circumstances of this case. To permit Respondent to hold out for some "reasonable concession" by the Union in return for the checkoff requirement would imply that the Respondent is now being ordered to surrender a position that it had legitimately maintained. Such an implication would be contrary to our finding, affirmed by the Court of Appeals, that Respondent's opposition to granting checkoff was based solely on a desire to thwart the consum[m]ation of a collective-bargaining agreement. Accordingly, we shall vacate our initial order in this case and shall direct that Respondent grant a checkoff provision to the Union. ${ }^{93}$

In thus concluding the H.K. Porter case, the Board followed the lead of the court of appeals to the last, paying insufficient attention to the congressional mandate enunciated in section 8(d) and the Supreme Court's interpretation of that mandate in such cases as Insurance Agents" and American National Insurance. ${ }^{95}$ Although the "business reason" test reiterated in the supplemental order may well be the harbinger of new criteria for evaluating an employer's bargaining position on the checkoff, or even all bargaining stances taken by either side, intransigent employers will still not find it difficult to avoid granting

91 See notes 58-66 supra, and accompanying text.

92 As an alternative to cease and desist orders in refusal to bargain cases, Board Chairman Frank McCullough has proposed the use of $\S 10(j)$ injunctions. McCullough, New NLRB Remedies, 30 U.S.L.W. 2133 (1961). This remedy would probably accelerate enforcement of Board orders, but doubts have been raised as to its efficacy and wisdom, specifically in light of this country's experience with labor injunctions. Id. at 2133-34; Ross, supra note 80, at 318-19. See F. Frankfurter \& N. GreEne, The Labor Injunction (1930)

93 H.K. Porter Co., 172 N.L.R.B. no. 72, 68 L.R.R.M. 1337 (1968).

94 NLRB v. Insurance Agents' Int'l Union, 361 U.S. 477 (1960).

95 NLRB v. American Nat'l Insur. Co., 343 U.S. 395 (1952). 
a checkoff. Since, in addition to expense, use of the checkoff as a bargaining counter is a permissible reason for denying the union's demand, employers might set the terms for agreement on a checkoff so prohibitively high as to circumvent their 8(a)(5) obligation.

The supplemental opinion is symptomatic of the approach used by both the Board and the court. By what reasoning can the Board condemn an employer for trying "to thwart the consum[m]ation of a collective-bargaining agreement," when in fact it signed one, forwarded it to the union, and the union signed it in turn? Surely one cannot refuse to agree to a contract and agree to a contract at the same time.

What the Board is probably trying to say is that, while refusing to accede to a checkoff proposal, the company offered the union a contract which it knew was unacceptable to the union, and by so doing tried to thwart agreement. But the streets are not paved with gold. The National Labor Relations Act is not a license for unions to be strong and employers to be weak, or vice versa. Rather, the simple fact underlying this case, which the Board has refused to recognize, is that the union lacks muscle. And while it is not difficult to paint the employer as a villain-indeed the case may be viewed as a reflection of both the Board's and the court's justifiable distaste for what they perceived to be the union-busting tactics of H.K. Porter and similar employers throughout the South-the employer did not violate section $8(a)(5)$ by playing it tough with a weak union. Less subtle means have been utilized by more recalcitrant employers..$^{96}$ Indeed, strong unions have been known to play it rough with weak employers. ${ }^{97}$ The Board must understand that the Act has been successful because, as the Court has long recognized, it is power-not benevolence or altruism-that makes the system go.

The real vice of H.K. Porter, however, is that the Board and the court are laying the foundation for finding $8(a)(5)$ violations on only the skimpiest of evidence. ${ }^{98}$ Further, in fashioning a remedy to deal with these violations, they are moving toward regulation of the substantive terms of bargaining agreements. The Board and the court should recognize that, while in the short run reliance on the parties' economic strength may increase friction and strife, in the long run it may well promote mutual understanding, thereby lubricating the bargaining process and making agreements easier to achieve.

96 See M. Kempton, Part of OUR Time 263-98 (1955).

7 See, e.g., R. \& E. JAMEs, HOFFA AND THE TEAMSTERS (1965).

88 See Alba-Waldensian, 167 N.L.R.B. no. 101 (1967), where the Board found that the employer's reasons for refusing to grant a checkoff were weak and were answered by the union with "reason and restraint." From this, the Board found an 8(a)(5) violation, citing $H . K$. Porter. While there was other evidence supporting the Board's conclusion, there can be little doubt that the violation was grounded largely on the refusal to grant a checkoff. 